\title{
Three Lines of Defense: Paradigm Supporting Roles of Internal Audit to Prevent Corruption in Indonesia Regional Government
}

\author{
Tarjo $^{1}$, Alexander Anggono ${ }^{2}$, Siti Musyarofah ${ }^{3}$, Bambang Haryadi ${ }^{4}$, Nurhayati ${ }^{5}$, Ach Fawaid As'ad ${ }^{6}$, \\ Sugiarto Mulyawan ${ }^{7}$ \\ \{tarjo@trunojoyo.ac.id ${ }^{1}$, alexander.anggono@trunojoyo.ac.id ${ }^{2}$, sitimusyarofah@trunojoyo.ac.id ${ }^{3}$, \\ bambang.haryadi@trunojoyo.ac.id ${ }^{4}$, nurhayati@trunojoyo.ac.id ${ }^{5}$, fhawaid01@ gmail.com 6 , \\ mulyawansugiarto07@gmail.com ${ }^{7}$ \}
}

Department of Accounting, University of Trunojoyo Madura ${ }^{1,2,3,4,5,6,7}$

\begin{abstract}
The purpose this article is to reference an internal audit structure for Regional Government in Indonesia. This article uses literature review from previous research to build a new audit concept. This article finds the reality contradicts between the practice and theory of internal audit that it is unable to fight corruption in Indonesia. In fact, the Komisi Pemberantasan Korupsi (KPK) and Indonesia Corruption Watch (ICW) released that the most corruption cases in Indonesia were dominated by corruption of goods and services procurement. Findings reflect a new paradigm, the concept of three lines of defense as a powerful supporting the role of internal audit to prevent corruption in Regional Government in Indonesia maximally.
\end{abstract}

Keywords: internal audit, regional government, corruption, three lines for defense

\section{Introduction}

Internal audit in Regional Government in Indonesia is often questioned its existence to prevent fraud. It is shown by many corruption cases involving Regent, Mayor, and Governor as the main actor or taking part in it. This phenomenon illustrates that internal audit is not effective in preventing fraud, even though the role of internal audit is in the second place after report in preventing and detecting fraud [1].

A contradictive failure happens related to the concept of internal audit quality in the public [2]. Public perception leads to many critics to the professionalism of internal audit which has an important role in preventing fraud. Internal auditor sometimes needs to sacrifice their professional assessment to serve the management interests [3]. It includes their independent to serve the top management in an organization governance [4]. Moreover, the minimum quality of the audit is due to poor working experience, professional assessment, no support from senior management, and misconception of the roles of internal auditor in the organization governance [5].

Theoretically, the function of internal audit can fight against the corrupt behavior [6]. Since 1991, internal audit has a role to evaluate the operation performance, assess the adequacy of an internal control system, ensure the reliability of financial report, provide the relevant information in decision making process, and evaluate the prevention and detection of fraud [7]. A quality audit process is consistent to the three principles of independence, professional, and awareness to fight against corrupt behavior [8]. Therefore, internal audit must comply with the auditing standard, audit technique, and audit assessment to prevent and detect fraud [6]. In determining mission of audit and early risk identification, it is important to ensure the quality of audit by the auditor [9].

The reality of the practice and theory is contradictory. When the theory of internal audit can fight against corrupt behavior [6], [8], the practice says the opposite; the internal audit cannot prevent corruption cases since the auditors sacrifice their professional assessment in serving the interest of top managers [4]. They often go grey independence, where their independence is grey in giving the assurance [3].

The corruption phenomenon in Indonesia is a global trend when it reached an index of 32 in the red zone (International, 2018). 42\% corruption dominated the goods and services procurement [10]. This fact shows that internal audit has failed in preventing corruption in Indonesia. What is actually happen to 
the discrepancy between the theory and actual practice of internal audit? This article is re-oriented the roles of internal audit and associated it with three lines of defense concept to prevent fraud.

\section{The Concept of Three Lines of Defense}

The role of internal auditors who fail to protect fraud scandals is a public problem on financial accountability [25]. The public interest is also threatened when the auditors cannot provide definite statements in their audit regarding financial accountability [26]. As a result, an internal control concept emerges and create a new paradigm called three lines of defense concept [27]. This model is used as the planning of risk management strategies and risk control in organizational governance. The concept of three lines of defense is part of the internal control-integrated framework which serves as a control structure in the organization [28]. The control and risk management system cannot stand alone as a whole with the role of internal audit. Internal auditor works as a supervisor and consultant for management within the organization [3].

Looking at previous studies that internal control plays a significant role in preventing and detecting fraud [29]-[31], it turns out that the internal control system used by private or public entities is very effective to control and mitigate the risks faced by organizations [32]. The system strongly supports organizational management that include control environment, risk assessment, control, information and communication, and monitoring, in which all are capable to prevent and detect fraud [32]-[34].

Public interest in the future is important to recommend the latest supervisory structure that is better than before [28], [35] in order to create financial accountability as the responsibility of internal auditors. In [36], a more reliable supervisory structure is designed, and it is known as a concept of three lines of defense. This concept is a risk defense pattern that can be used by the entities, where the first line of defense is audit and risk management responsibility, the second line of defense is risk management responsibility, and the third line of defense is internal auditor responsibility [37]. This system collaborates risk management and internal auditor with the task and responsibility of formalizing the risk management process with internal audit, serving the interests of internal audit on risk management, and collaborating internal audit and risk management in risk assessment and audit planning. Conceptually, it can be seen in the figure below:

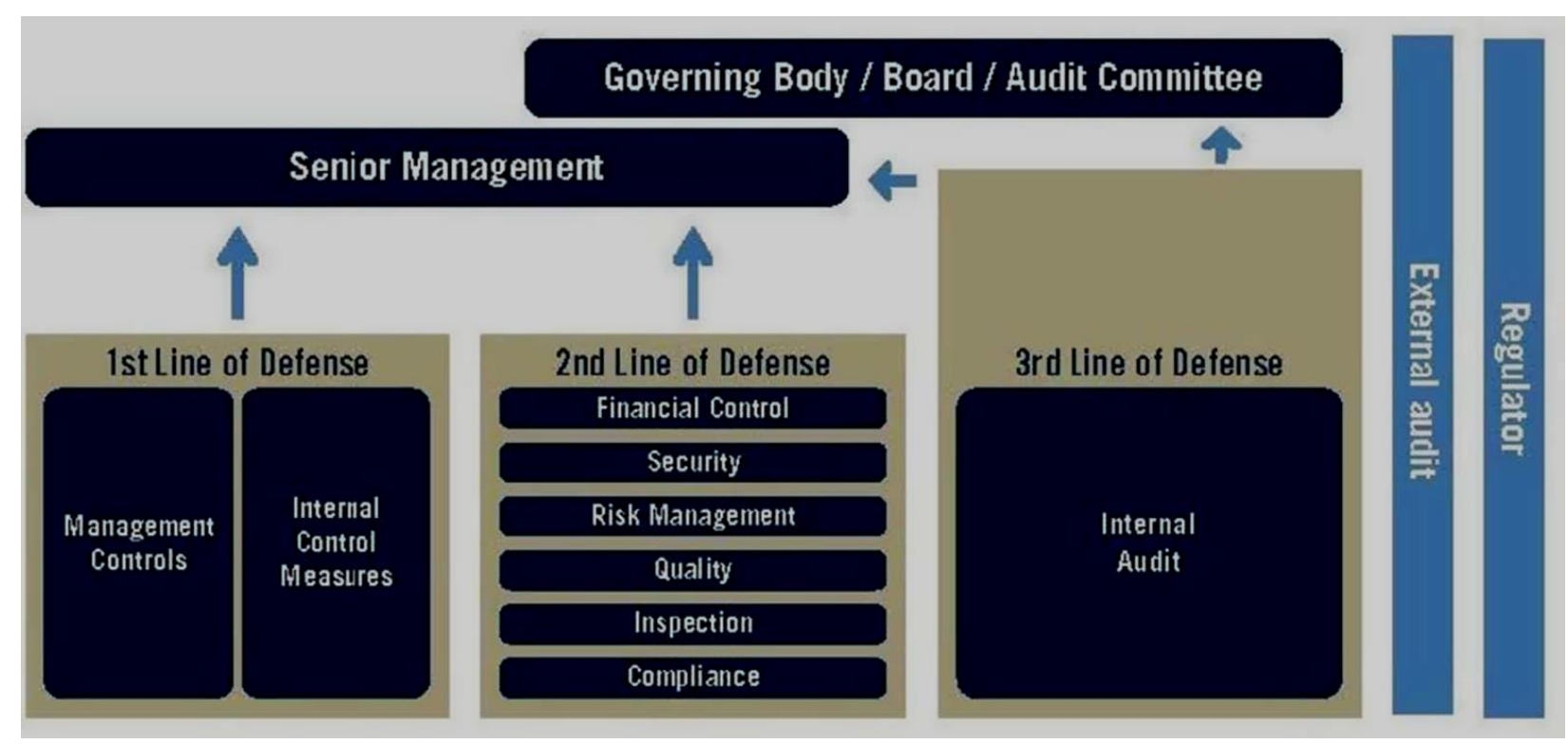

Figure 1. Structure of Three Lines of Defense Data source: Concept of Three Lines of Defense (IIA, 2013) 
The defense model as illustrated in the concept above illustrates that the first line of defense has risk management function, the second line of defense has risk management function and compliance with regulation, and the third line of defense has the function of providing an independent internal audit guarantee. This model is a new paradigm that changes the perspective of risk management in an integrated manner between risk management and internal audit [38], [39]. It is a system performance that can mitigate risk simultaneously to achieve organizational goals [40]. In conducting audit planning, auditors can communicate with the risk management to find out which post audit to be conducted. So, the risk responsibility in organizations is not only borne by internal auditors, but also by risk management who give support [26].

Audit planning and early risk detection provide objective professional assessment to notify the warning sign to the auditee in order to immediately expose the risks responsively and effectively [37]. This is not just an innovation in the control system, but also a new challenge in developing and practicing a more complex supervisory structure [25]. The new standard compiled by [36] is one of the reference forms of guidelines for audit practice and risk management as a shared responsibility [41]. Along with the complexity of organizational challenges in business orientation or serving the public interest, sometimes integral miscommunication occurs, in which hinders overall governance in the organization [42]. It is important for each element in the structure of Three Lines of Defense to establish good communication [17].

The concept of the Three Lines of Defense provides a new illustration of the supervision phenomenon that occurs in governance in Indonesia. This concept can be used as a reference for internal supervision structure development pattern. The transformation leading to institutional reform of an institution to realize effective, efficient and economical organizational governance is very important and it can be done by strengthening the role of internal audit and risk management [43]. This method is a pattern that can provide support for the role of internal audit in preventing and detecting fraud risk in the form of corruption [6]. If this model is used, it can provide significant functions starting from the efficiency and effectiveness of operation, asset security, reliability, and integrity of the reporting process, and compliance with applicable regulations [41]. Indirectly this will provide a new control phenomenon in mitigating risk [44]. Indeed, all efforts must be made to fight corruption in governance, especially in Indonesia where the level of corruption is still in the red zone.

\section{Methodology}

This research used the qualitative approach with literature study as the analysis materials. Literature study was chosen to analysis the previous studies on the position of internal audit in fighting corruption. Moreover, the analysis would be followed by practice phenomenon of internal audit from one of Regional Government in Indonesia. Due to the contradiction between the theory and practice, this article designed a new audit concept in order to prevent corruption in Indonesia. In the context of Indonesian bureaucratic reform, the Internal Auditor (APIP) has not yet applied the three lines of defense model (see, Law No 12 of 2017, Instruction of the Minister of Home Affairs Number 900/918/SJ, Law No.8 of 2006, Law No 60 of 2008, and Regulation of the Ministry of State Apparatus and Civil Service Reform (PermenPAN-RB) No 9 of 2009). It is because the three lines of defense system has all the aspect as an integrated unity to mitigate the risks.

\section{Contradiction between Corruption and Arguments for Intern Audit}

Internal audit by APIP in the Regional Government in Indonesia is unassertive to include corrupt behavior as the part of fraud concept. Therefore, the Audit Report (LHP) by the auditors never stated "corruption" or "fraud", instead, it only stated loss and damage to the State financial. This definition has a crucial difference between fraud and corruption [11]. Consequently, when APIP do an investigation, they are afraid to include corruption in the report. In fact, corruption is under the fraud tree, including misappropriation and financial statement fraud [12].

Regulation on criminal acts of corruption in Indonesia is within the scope of public sector. Law number 31 of 1999 of article 2 and 3 reads:

"Anyone unlawfully enriching himself and/or a corporation in such a way to be detrimental to the finances of the state or the economy of the state shall be liable to life in prison (...)" and reads: 
"Anyone with the intention of enriching himself or other persons or a corporation, abusing the authority, the facilities or other means at their disposal due to rank or position in such a way that is detrimental to the finances of the state or the economy of the state, shall be liable to life imprisonment or a prison of (...)"

The highlighted phrase means that it indiscriminate any who involving with the finances of the state. Definition of corruption lies at the purpose or intention to enrich himself, other persons or a corporation which is detrimental to the finance of the state.

Definition of the regulation on criminal acts of corruption in Indonesia is in line with its article [13] stating that corruption is a form of abusing the authority, power, and available sources to enrich himself. There is a nuance of monopoly of authority without accountability in managing the finances of the State [11]. Their corrupt behavior also rationalized financial statement fraud for their own interests [14]. Corrupt behavior is influenced by political, social, and culture environments [15]. Not to mention the social-culture of corruption in Indonesia, almost all lines in the government from the central to the regional has its own means in abusing the finances of the State. Therefore, it is unsurprising that the corruption index of Indonesia is in the red zone.

Those statement above finally shows the definition of corrupt behavior leading to the severe part of fraud cases. An accumulated fraud in an overall aspect starting from the abuse of trust, intention, mistakes, levity representing the material loss, so it causes victim [16]. Meanwhile, corruption does not mean fraud only, but the abuse of authority and power which can control the financial function for the benefit and interest of himself, a group or even a corporation.

Internal audit stated in the audit report shows that APIP is generally competent in its responsibility to prevent and detect fraud, but they did not include corruption case explicitly in its report [6]. Corruption can only be revealed when the external parties enter, such as external auditors and law enforcement officers [11]. Internal auditors are required to have a good communication pattern with the auditee, external auditors, and law enforcement officers to fight against fraud in the internal organization [17]. When the internal auditors are disturbed their independence, then the assurance recommendation is not followed up by the management, the auditors have the right to communicate their findings with the external parties in order to fight the corrupt behavior within the organization.

Confirmed party from APIP of the internal auditors of Regional Government in Indonesia argue that they are often threatened by the management in conducting the professional assessment. There is a conspiracy to get rid of the findings by the auditor since it is considered disturbing the interest of management. APIP has no other way than keep it off the record the findings stated in the results for inspection points (P2HP) as a saving evidence on their desk. The argument of APIP is as follows:

"The findings concealed by the management (auditee), we save it on our desk. Someday, when it is raised as a case to the court, we will show our findings. We keep everything secret, unless BPK (external auditor) or the prosecutor ask it for a legal evidence and we will come as witnesses (Mr. Bud, APIP in a Regional Government in Indonesia)".

Efficiency, effectiveness, and economics of the internal supervision function in Indonesia related to the copy of tiered findings communication have not been performed correctly. The tiered audit reports are submitted to the Regent as the Regional Head, Audit Board of Indonesia (BPK-RI) of Provincial Representative, National Government Internal Auditor (BPKP) of Indonesia of Provincial Representative, and Provincial Inspector, as stipulated in the Regent Regulation related to Audit Follow-Up in Regional Government. Politically, the administration has fulfilled the criteria of good governance, but it is not with the deliberately omitted findings, so it only ends on the auditor's work table.

In the authentic evidence that proves the inability of internal audits to fight corruption, there are cases of political corruption in the Regional Government implied, especially in the fraud cases of procurement of goods and services. In Indonesia, there are state financial loss records from corruption cases of procurement of goods and services by Rp. 1,133.5 trillion [10]. Procurement activity is an easy target for corruption actors due to three aspects: the majority of government financial management involving large financial resources, procurement activities that are not separated from transactional politics between providers and politicians, and frequent budget manipulation [18]. The mindset of contemporary capitalism then leads to corrupt behavior [19]. Bureaucrats (procurement parties) are an inseparable part who take part in the political corruption arena [20]. An integrated control systems are 
damaged only due to is collusion between sectors that should become the responsibility of accountants and auditors [21].

Collusion between parties takes place in groups with the aim of enriching themselves and their groups [22]. Intentionally, there is a significant relationship between providers (who fund political campaigns in democracy) and politicians, and here the providers demand the projects promised by the elected politicians [19]. With the intention to collude, it shows a moral degradation that eventually becomes a culture in its territory [23]. As the elected politicians, they have authority that lacks accountability that can be accounted for. So, it is not surprising if the providers are ready to buy the politician's authority as a democracy momentum in making choices [24].

\section{Conclusion}

Theoretically and conceptually it is revealed that internal audit can fight corruption by preventing and detecting fraud in internal organization [4]-[7], [9]. However, the reality shows that internal audit practices in the field cannot prevent and detect fraud, especially corruption of procurement of goods and services in the Regional Government in Indonesia. In the Audit Report (LHP), the internal auditor's statement in exposing the corruption concept inside has not been found. In fact, there is a political corruption phenomenon in group to enrich themselves or others for their own sake. Therefore, this article finds a new paradigm that designs internal control structures in internal organization. The new model collaborates the risk management and internal audit. It has a function is to maximize the support assurance in mitigating risk since the early stage to finalize the audit planning process. There is a concept of Three Lines of Defense consisting of first line of defense (audit and risk management responsibility (Internal Audit Leader)), second line of defense (risk management responsibility), and third line of defense risk (internal auditor responsibility).

\section{References}

[1]ACFE, Report to the nation 2018 global study on occupational fraud and abuse. 2018.

[2]M. F. Razali, J. Said, and J. R. JOhari, "Internal auditor's objectivity threats : an exploratory study in Malaysia," Proc. Int. Conf. Account. Stud., no. August, pp. 15-18, 2016.

[3]M. Roussy, "Critical perspectives on accounting internal auditors' roles : from watchdogs to helpers and protectors of the top manager," Crit. Perspect. Account., vol. 24, pp. 550-571, 2013.

[4]Jamaludin, M. Ali, Mediaty, and Syarifuddin, "Effects of independence mediation on the influence of role ambiguity, role conflict and auditors 'competence towards internal audit quality," J. Res. Bus. Manag., vol. 2, no. 10, pp. 33-40, 2014.

[5]M. Odar, B. Korosec, and R. Horvat, "Development and the current profile of internal auditing - the results of the two empirical studies in Slovenian organisations," Tour. Hosp. Manag., vol. 12, no. 2, pp. 55-69, 2006.

[6]K. K. Jeppesen, "The role of auditing in the fight against corruption," Br. Account. Rev., 2018.

[7]N. Tabara and M. Ungureanu, "Internal audit and its role in improving corporate governance systems," Ann. Univ. Apulensis Ser. Oeconomica, vol. 14, no. 1, pp. 139-145, 2012.

[8]M. Gustavson and aksel Sundstrom, "Organizing the audit society: does good auditing generate less public sector corruption?," Adm. Soc., pp. 1-25, 2016.

[9]A. N. C. Lucan, E. Hlaciuc, and A. Maria, "The impact and results of the internal audit activity exercised in the public sector in Romania .," Procedia Econ. Financ., vol. 32, no. 15, pp. 394-399, 2015. [10]ICW, "Tren penindakan kasus korupsi tahun sektor pengadaan barang dan jasa 2017," Indones. Corrupt. Watch, pp. 1-31, 2017.

[11]IFAC., "FAC (1999). The accountancy profession and the fight against corruption, discussion paper," available https://web.archive.org/web/19991127080028/http://www.ifac.org/Council/AntiCorruptionPap er.html Accessed 22.01.19., 1999.

[12]T. A. Pearson and T. W. Singleton, "The digital environment," vol. 23, no. 4, pp. 545-559, 2008.

[13]M. Johnston, "The search for definitions: the vitality of politics and the issue of corruption," in International Social Science Journal, 1996, pp. 321-335.

[14]O. J. Stalebrink and J. F. Sacco, "Rationalization of financial statement fraud in government An Austrian perspective," Crit. Perspect. Account., vol. 18, pp. 489-507, 2007. 
[15]J. L. Bierstaker, "Differences in attitudes about fraud and corruption across cultures Theory, examples and recommendations," Cross Cult. Manag. An Int. J., vol. 16, no. 3, pp. 241-250, 2009.

[16]W. S. Albrecht, C. C. Albrecht, chad o ALbrecht, and M. Zimbleman, Fraud examination. 2009.

[17]L. Ferry, Z. Zakaria, Z. Zakaria, and R. Slack, "Watchdogs, helpers or protectors? - Internal auditing in Malaysian local government," no. August 2016, pp. 1-15, 2017.

[18]D. Neu, J. Everett, and A. S. Rahaman, "Internal auditing and corruption within government: the case of the Canadian sponsorship program," Contemp. Account. Res., pp. 1-29, 2012.

[19]P. Sikka and G. Lehman, "Critical perspectives on accounting the [ 1 _ TD \$ IF ] supply-side of corruption and limits to preventing corruption within government procurement [ 2 _ TD \$ IF ] and constructing ethical subjects §," Crit. Perspect. Account., pp. 1-9, 2015.

[20]D. Neu, J. Everett, and A. S. Rahaman, "Critical perspectives on accounting preventing corruption within government procurement: constructing the disciplined and ethical subject," Crit. Perspect. Account., pp. 1-13, 2014.

[21]J. V Everett, D. Neu, and A. S. Rahaman, “Accounting and the global W ght against corruption,” vol. 32, pp. 513-542, 2007.

[22]Alfian, "Pemetaan jenis dan risiko kecurangan dalam audit pengadaan barang dan jasa," $J$. Pengadaan, vol. 4, no. 1, pp. 1-19, 2015.

[23]J. Everett and M. Tremblay, "Critical perspectives on accounting ethics and internal audit : moral will and moral skill in a heteronomous field," Crit. Perspect. Account., 2013.

[24]S. E. Scarrow, "Political finance in comparative perspective," Annu. Rev., vol. 10, pp. 193-210, 2007. [25]A. D. Chambers, "New guidance on internal audit - an analysis and appraisal of recent developments," Manag. Audit. J., vol. 29, pp. 196-218, 2014.

[26]A. D. Chambers, "The current state of internal auditing: a personal perspective and assessment," $e d p$ audit. control. Secur. Newsl., vol. 49, no. April 2015, pp. 1-14, 2014.

[27]D. J. Anderson and G. Eubanks, "Leveraging coso across the three," Comm. Spons. Organ. Treadw. Comm., 2015.

[28]COSO, "Internal control - integrated framework," release Exec. Summ. www.coso.org, pp. 1-8, 2013. [29]I. Abiola, "Internal control system on fraud detection: Nigeria experience Ladoke Akintola University of Technology Ladoke Akintola University of Technology," J. Account. Financ., vol. 13, no. 5, pp. 137-149, 2013.

[30]J. M. Altamuro and A. Beatty, "How does internal control regulation affect financial reporting ? how does internal control regulation affect financial reporting?," J. Account. Econ., vol. 49, pp. 58-74, 2010.

[31]R. Baxter and J. C. Bedard, "Enterprise risk management program quality: determinants, value relevance, and the financial crisis," Contemp. Account. Res., vol. 30, p. 4, 2013.

[32]T. Aabo, J. R. S. Fraser, and H. One, "The rise and evolution of the chief risk officer : enterprise risk management at hydro one," J. Appl. Corp. Financ., vol. 17, no. 3, pp. 62-75, 2005.

[33]K. A. Adetiloye, F. O. Olokoyo, and J. N. Taiwo, "Fraud prevention and internal control in the Nigerian banking system," Int. J. Econ. Financ. Issues, vol. 6, no. 3, pp. 1172-1179, 2016.

[34]M. Feng, C. Li, S. E. McVay, and H. Skaife, "Does ineffective internal control over financial reporting affect a firm's operations? Evidence from firms' inventory management," Account. Rev., vol. 90, no. 2, pp. 529-557, 2015.

[35]COSO, "Enterprise risk management - integrated framework," in www.aicpa.org, no. September, 2004.

[36]IIA, "Internal auditing's role in corporate governance," Position Pap. from. https// na.theiia.org/, pp. $1-4,2018$.

[37]Suryaningrum, "Auditor intern respons atas resiko fraud," lanskap prakt. audit. intern. Indones. Jakarta IIA Indones., no. June, 2017.

[38]IIA, "The three lines of defense in effective risk management and control," Position Pap. from https// na.theiia.org/standards-guidance/Public\%20Documents/PP\%20

The\%20Three\%20Lines\%20f\%20Defense\%20in\%20Effective\%20

Risk\%20Management\%20and\%20Control.pdf, no. January, 2013.

[39]KPMG, "The three lines of defense: Making the transition to a mature risk management model," Retrieved from. http//www.investopedia.com/terms/c/closely-held-corporation.asp more Inf. Defin. a closely held Corp., 2016. 
[40]Basel, Basel committee on banking supervision, the internal audit function in banks, bank of international settlements, no. June. 2012.

[41]I. Arndorfer and A. Minto, "The 'four lines of defence model' for financial institutions," ISSN 10209999 (online). Retrivied from . Http//www.bis.org/, no. 11, 2015.

[42]K. Doughty, "Guest editorial the three lines of defence related to risk governance," ISACA JOURNAL. Retrivied from. (www.isaca.org/journal), vol. 5, 2011.

[43]T. Rustendi, "Peran audit internal dalam memerangi korupsi (upaya meningkatkan efektivitas fungsi APIP)," J. Akunt., vol. 12, no. 2, pp. 112-126, 2017.

[44]M. Arena, M. Arnaboldi, and G. Azzone, "The organizational dynamics of Enterprise Risk Management,” Accounting, Organ. Soc., vol. 35, no. 7, pp. 659-675, 2010. 